\title{
IMPLICATION OF FLOWER COLORS TO HUMAN BEINGS AND INSECTS
}

Shamanta Iyengar

Prof. Botany Govt. P.G.College Rampura

\section{ABSTRACT}

Flowers owe their beauty to their infinite range of shapes and colours and are symbolized with spiritualism and expression, conveyance of sentiments of human beings. On the other hand plants employ flowers to form association with animals to ensure pollination across multi generation. To achieve this they provide clues and positive enforcements. The diversification in flower colours and other attributes has matched in nature with co-evolution of abundant species of insects. This paper deals with the perception of flower colours by insects and also their denotions to human beings.

Key words- symbolism, perception

Flowers are appreciated for the beauty of their colorful and scented blooms. They are considered as wonderful creation of nature. Flowers exhibit virtually endless variety of spectral signatures. Perception of this spectrum of color stimuli is found to trigger corresponding emotional and behavioural responses in human beings . The practice of assigning symbolic meanings to flowers is known as floriography. Some of the meanings are depicted in table.

Table 1 -Symbolism of flower colors

\begin{tabular}{|c|c|}
\hline Color & Symbol \\
\hline Deep blue & Peace, openness, serenity, vastness \\
\hline Pink & Grace, happiness, admiration gratitude \\
\hline Purple & Dignity, pride, success \\
\hline Red & Passion, desire, love \\
\hline White & $\begin{array}{c}\text { Innosense, reverence, purity, simple beauty, } \\
\text { chastity }\end{array}$ \\
\hline Yellow & Joy, friendship, caring, platonic emotion \\
\hline Orange & Enthusiasm, warmth, confidance, fascination \\
\hline Green & Youth, optimism, resilence, harmony \\
\hline Black & Death, farewell, death of relationship, annoyance \\
\hline
\end{tabular}

The color of flowers not only entice human beings but also insects. Preference for flower color has been shown by number of studies (Pederson 1967, Kay 1976, Lelegi 1973).

Table- 2- Flower colour attraction of insects

\begin{tabular}{|c|c|}
\hline Insect type & Flower color to which they are attracted \\
\hline Bees & Blue, Yellow \\
\hline Beetles & White, cream, green \\
\hline Butterflies & Strong pink, red \\
\hline Moth & Cream \\
\hline Wasp & Purple, blue \\
\hline
\end{tabular}


Relationship of flowers and insects is one of benefit and enhancement. Flowers provide nutrition in the form of nectar while insects help in cross pollination i.e. in transferring male genetic material in the form of pollen to female organ, gynoecium of another flower, the color of flower is attributed to the presence of phytochemicals Anthocyanins classified as flavanoids. Their color depends on the $\mathrm{pH}$ of the cell sap eg. Pink in acidic, purple in neutral, greenish and yellow in alkaline solutions. (Harborne 1988, Michaelis, Schuburt and Smythe 1936). Flavonoids are polyphenolic compounds that are ubiquitous in nature and are categorized according to chemical structure into flavonols, flavones, flavanones, isoflavones, catechins, anthocyanidins and chalcones. The floral flavanoids often in combination with UV reflective carotenoid pigments form UV visible patterns. (Harborne and Grayer 1994 in Annual Review) which are visible to insects but not to humans. According to Guldberg and Alstart (1975) flowers of about $33 \%$ of all species strongly reflect UV light. This reflection pattern provides the pollinator with the appropriate clues of the location of nectaries and of individual flower in inflorescence thereby fascilitating orientation of insects on flower for the transfer of pollens. The reception of UV patteren plays a role in selection of flower by insects.

Insects cannot perceive red but are capable to see other colors including UV light (Lubbock 1882). Honey bees have been shown to perceive the sum of two primary colors as a new color. So the part of a flower that emits yellow and UV light (UV is a primary to insects) well appear as bee purple to honey bee. (Thomas einer 2002). Some flowers show color change eg. Lupinus, (Gori 1989) Lung worts, forget- me- not, Delphinium (Perry) sending a cue to the insects that a flower is in later stages of development and/ or post pollinated stage and that there is a change in nectar \& pollen availability. In this way flowers advertise honestly about their unrewarding state and convey insects not to waste energy by visiting them.

Weiss 1991, Pedersen 1967, Leleji 1973 and Kay 1976 have also reported selection of flower colors by insects.

Thus pollinator behaviour is influenced by morphology and chemical characteristics of flowers. Diversity in floral pattern has aided in evolution of enormous variety of insects (Cruden, Hermann and Peterson 1983 ) thereby beautifying the nature. In this way flowers are said to fulfil the basic purpose of creation. "Live and Let Live". Each niche in the nature serve dual purpose one for its own i.e. survival and reproduction and secondly contribute to the flourishing of other individuals. It is this principle that underlines the harmony and oneness found throughout nature.

\section{REFERENCES}

1 Cruden R.W., Hermann S.M. and Peterson (1983) Patterns of nectar production and plant pollinator colvolution In Benltey B.\& Eliss, T. (Eds) The Biology of Nectaries Newyork Columbia Univ. Press 82-125

2 Gori D. F. (1989). Floral color change in Lupinus arenteus (Fabaceae) Why should plant advertise the location of unrewarding flowers to pollinators? Evolution 43:870-882

3 Guldberg L.D. and P.R. Atsatt(1975) Frequency of reflection and absorption of ultraviolet light in flowering plants, The American Midland Naturalist 93:35-43 


\section{INTERNATIONAL JOURNAL of RESEARCH -GRANTHAALAYAH \\ A knowledge Repository}

Art

4 Harborne J.B. (1988). Biochemistry of plant pollination In: Harborne J. B. (ed.) Introduction to Ecological Biochemistry London: Academic Press, $3^{\text {rd }}$ ed, 42-81

5 Kay Q.U.N. (1976) Preferential pollination of yellow flowered morphs of Raphanus Raphanistrum by Pheris and Eristalis spp. Nature 261:230-232.

6 Kavin Davies (2009) Annual plant Reviews, Plant, Pigments and their Manipulation, Retrieved on 11 nov 14 www. books. google.co.in/books? isbn

7 Lubbock J. (1882)- Ants vees and wasps. Kegan Trench and company London.

8 Leliji O.I. (1973) Apparent preference by vees for different flower colors in cowpeas (Vigna senensis L. savi ex. Hassk.) Euphytica 22, 150-153.

9 Pederson H.W. (1967) Cross pollination studies involving three purple coloured flowered alfalfas, one white coloured line and two pollinator species Crop Sci.7.59-62

10 Thomas Eisner (2002) An insects view of a flower American Entomology 142-143

11 Perry P. Leonard Color in flowers Univ of Vermont 01124. Retrieved on 11 nov 14 from www.pss.uvm. edu/pep/pules/oh 24 colr. htm.

12 Weiss M.R. (1991) Floral colour changes as cues for pollinators Nature 354:227-229

13 Michaelis Leonor, Schubert M.P. and Smythe C V (1936) Potentiometric study of the Flavins J. Biol. Chem. 116(2) 587-607. 